\title{
Functional properties and proximate composition of cactus pear cladodes flours
}

\author{
Propriedades funcionais e composição centesimal de farinhas dos cladódios de palma forrageira
}

\author{
Jaime LÓPEZ-CERVANTES ${ }^{1 *}$, Dalia Isabel SÁNCHEZ-MACHADO ${ }^{1}$, \\ Olga Nydia CAMPAS-BAYPOLI ${ }^{1}$, Carolina BUENO-SOLANO ${ }^{1}$
}

\begin{abstract}
The objective of this research was to study the functional properties and proximate composition of three different flours prepared from cactus pear cladodes. Immature cactus pear cladodes were dried at $60{ }^{\circ} \mathrm{C}, 70^{\circ} \mathrm{C}$ and $80{ }^{\circ} \mathrm{C}$. The flours were analyzed for chemical composition, amino acid profile, fatty acid composition, functional properties and color. The analyses showed no significant differences in crude protein, total lipid, crude fiber and total ash content in the flours, possibly due to the drying temperature effect. Nevertheless, during the drying at $80^{\circ} \mathrm{C}$, a reduction of the water holding capacity (55\%) was observed, along with a reduction of the green color intensity (34\%) - characteristic of cactus pear. The heating produced larger concentrations of tyrosine, proline, aspartic acid, and glutamic acid. In the lipids of the flours, the most abundant fatty acids were palmitic acid (C16:0), linoleic acid (C18:2n6), linolenic acid (C18:3n3), and oleic acid (C18:1n9). The cladodes flours prepared at $60{ }^{\circ} \mathrm{C}$ presented a higher quality regarding their nutritional and functional properties.

Keywords: food analysis; edible cactus; drying process; vegetable powders; technological properties.
\end{abstract}

\section{Resumo}

O objetivo desta pesquisa foi estudar as propriedades funcionais e a composição centesimal de três diferentes farinhas preparadas dos cladódios da palma forrageira. Palmas forrageiras não maturadas foram secadas a $60^{\circ} \mathrm{C}, 70^{\circ} \mathrm{C} \mathrm{e} 80^{\circ} \mathrm{C}$, e as farinhas obtidas foram analisadas na sua composição química, no perfil dos aminoácidos, na composição de ácidos graxos, nas propriedades funcionais e na cor. Não houve diferenças significativas nos teores de proteína bruta, lipídios totais, fibra bruta e de cinzas totais nas farinhas pelo efeito da temperatura de secagem. No entanto, durante a secagem a $80^{\circ} \mathrm{C}$ foi observada uma redução da capacidade de retenção de água (55\%) e da intensidade da cor verde (34\%), característica da palma forrageira. A tirosina, a prolina, o ácido aspártico e o ácido glutâmico foram encontrados em alta concentração. Nos lipídios das farinhas os ácidos graxos mais abundantes foram o ácido palmítico (C16: 0), o ácido linoleico (C18: 2n6), o ácido linolênico $(\mathrm{C} 18: 3 \mathrm{n} 3)$ e, o ácido oleico $(\mathrm{C} 18: 1 \mathrm{n} 9)$. As farinhas dos cladódios da palma forrageira preparadas a $60^{\circ} \mathrm{C}$ apresentaram uma alta qualidade em termos de suas propriedades nutricionais e funcionais.

Palavras-chave: análise de alimentos; cactus comestível; processo de secagem; pós vegetais; propriedades tecnológicas.

\section{Introduction}

Cactus pears are Opuntia genus plants of the Cactaceous family which are endemic in America (DE LA ROSA; SANTANA, 1998; GRANADOS, 2003). Freshly harvested Cactus pear cladodes are regarded as vegetables; they present a high content of water and a minor proportion of dietary fiber, lipids, proteins and calcium. Other constituents are antioxidants, such as ascorbic acid, $\beta$-carotene, lutein and xanthophylls (RODRÍGUEZ-FÉLIX; VILLEGAS-OCHOA, 1997; BETANCOURT-DOMÍNGUEZ et al., 2006). This plant is known for its medicinal properties, such as an auxiliary treatment for obesity, and gastrointestinal or cardiovascular disorders. These extracts also decrease the levels of cholesterol and serum glucose (OU et al., 2001; O'CONNOR et al., 2003; DUKAS; WILLETT; GIOVANNUCCI, 2003; LEE; CHUNG; LEE, 2006). The physiological effects, on the human organism, have been attributed to the functional properties that provide the dietary fiber (SÁENZ, 1997; SÁENZ et al., 2002; SÁENZ et al., 2006, FEUGANG et al., 2006).
In Mexico, cactus pear cladodes (nopalitos) were harvested from 10,929 ha (approximately 24,000 acres), in 2008, with the annual production of 596,856 ton (SISTEMA INTEGRAL DE INFORMACIÓN AGROALIMENTARIA Y PESQUERA, 2008). This vegetable has a short shelf life, from 3-4 weeks, and consequently, it is sold fresh in the commercial market. Some options that offer added value to cactus pear cladodes are their use for the production of flours, soups, jams, dehydrated sheets and desserts (SÁENZ, 2000).

Recently, the drying of cactus pear cladodes for the production of flours has been proposed as a viable nutritional alternative. People have used the flours as food ingredient (in corn tortillas) or as a nutritional supplement (powder, capsule or tablet). The advantages of the drying process are the microbial stabilization, reduction in storage and transport costs, in addition to the concentrating of nutrients (KWOK et al., 2004; TORRECILLA; ARAGÓN; PALANCAR, 2005).

${ }^{1}$ Departamento de Biotecnología y Ciencias Alimentarias, Instituto Tecnológico de Sonora, 5 de febrero 818 Sur, CP 85000, Obregón, Sonora, México, e-mail: jlopezc@itson.mx ${ }^{*}$ Corresponding author 
However, the drying process can have a negative influence on the nutritional value of foods. The high temperatures and the long drying time can result in a loss of nutritional value, color, taste and of functional properties of foods (KARATHANOS; VILLALOBOS; SARAVACOS, 1990; FEMENIA et al., 1999). The size and age of the cladodes determine their properties. The purpose of this study was to determine the functional properties and proximate composition of three different flours obtained from cactus pear cladodes. Our hypothesis was that the drying temperature has a significant influence on the cladodes nutritional and functional properties.

\section{Materials and methods}

\subsection{Plant material}

Immature cactus pear cladodes (Opuntia ficus indica), without spines and with $15 \pm 5 \mathrm{~cm}$ length, were purchased in the local marketplace (Cajeme, Sonora, México). All samples were washed with clean water, separated into lots of $6 \mathrm{~kg}$, and stored at $4{ }^{\circ} \mathrm{C}$ prior to processing.

\subsection{Flour preparation}

Each cactus pear cladode was cut lengthwise into a rectangular shape. Then, $6 \mathrm{~kg}$ portions were dried in convection oven at $60^{\circ} \mathrm{C}, 70^{\circ} \mathrm{C}$ and $80^{\circ} \mathrm{C}$ (Vortron mod. TR2-1600, Vortron Corp., Beloit, WI, USA). The researchers evaluated the moisture content, at 30 minutes intervals, to obtain drying curves during the drying process. The dried products were ground in a coffee grinder (CG100 series, Black \& Decker Corp., Towson, Maryland, USA) and passed through a sieve (mesh No. 30). All the flours were stored at $25^{\circ} \mathrm{C}$ prior to analysis.

\subsection{Proximate analysis}

The moisture content was determined by drying each sample to a constant weight, at $70{ }^{\circ} \mathrm{C}$. The nitrogen content was determined by the RapidKjeldahl method (Labconco, Model 652, Labconco Corp., Kansas City, MO, USA). The protein content was calculated by multiplying the $\% \mathrm{~N}$ by the factor 6.25. The ash content was determined gravimetrically through incineration at $550{ }^{\circ} \mathrm{C}$ for 8 hours. The crude fiber was quantified by the AOAC method (ASSOCIATION OF OFFICIAL ANALYTICAL CHEMIST, 1984). After that, each sample was subjected to acidic digestion $\left(\mathrm{H}_{2} \mathrm{SO}_{4} 0.255 \mathrm{~N}\right)$ followed by alkaline digestion ( $\mathrm{NaOH} 0.322 \mathrm{~N}$ ) for 30 minutes. In order to evaluate the total lipid content, the lipid was extracted from the samples with a 2:1 chloroform-methanol solution using the Sánchez-Machado et al. method (2004). Carbohydrates were determined by the difference between all other ingredients and the total.

\subsection{Determination of total amino acids}

\section{Protein hydrolysis}

Samples $(50 \mathrm{mg})$ were weighed in a tube with a screw cap, and then $10 \mathrm{~mL}$ of $6 \mathrm{M} \mathrm{HCl}$ was added. The solutions were incubated at $110{ }^{\circ} \mathrm{C}$ for 24 hours. The resulting solution was vacuum-filtered through Whatman no. 41 paper. The filtrate was diluted with ultra-pure water (Milli-Q) with the purpose of obtaining a final concentration of approximately $0.1 \mathrm{mg} \cdot \mathrm{mL}^{-1}$. Finally, $300 \mu \mathrm{L}$ of this solution was added to vials, in triplicate, and dried in a vacuum oven at $60{ }^{\circ} \mathrm{C}$ overnight. For the derivatization from amino acids with $\mathrm{FMOC}-\mathrm{Cl}$, the researchers used the López-Cervantes, Sánchez-Machado and Rosas-Rodríguez method (2006).

\section{Equipment and chromatographic conditions}

The chromatographic analysis employed an analytical scale $(4.6 \mathrm{~mm} \times 150 \mathrm{~mm})$ Zorbax Eclipse AAA C18 column with $5 \mu \mathrm{m}$ particle size (Termo Electron Corporation, Dandenong, Australia). The HPLC conditions were as follows: mobile phase A: $30 \mathrm{mM}$ ammonium phosphate $(\mathrm{pH}$ 6.5) in 15:85 (v/v) methanol:water; mobile phase B: 15:85 (v/v) methanol:water; mobile phase C:90:10 (v/v) acetonitrile:water. The flow rate was constant at $0.5 \mathrm{~mL} /$ minute and the column was a constant $38{ }^{\circ} \mathrm{C}$. The detection was determined by fluorescence, using the wavelengths of excitation and emission at 270 and $316 \mathrm{~nm}$, respectively. The elution gradient applied was: (Min/A\%:B\%:C\%): 0/8:79:13, 34/11:43:46, 36/11:43:46, 36.5/0:0:100, 38.5/0:0:100, 38.55/8:79:13, 50/8:79:13. The HPLC system (GBC, Dandenog, Victoria, Australia) was equipped with an LC 1650 auto injector, an online LC 1460 solvent degasser, a system controller with WinChrom for chromatography data analysis, a LC 1150 pump, a LC 1150 column oven, a $20 \mu \mathrm{L}$ injection loop (Rheodyne, Cotati, CA, USA) and a LC 5100 fluorescence detector.

\section{Fatty acid composition}

The fatty acid composition was determined through gas chromatography in accordance with the Sánchez-Machado et al. procedure (2004). All samples were analyzed in duplicate. The specific procedure: a $0.5 \mathrm{~g}$ sample was weighed in a tube with a screw cap and it was treated with $2 \mathrm{~mL}$ of toluene and $3 \mathrm{~mL}$ $\mathrm{HCl}$ methanolic 5\%. This mixture was vortexed and placed in water bath for 2 hours. After cooling to room temperature, $3 \mathrm{~mL} \mathrm{~K}_{2} \mathrm{CO}_{3} 6 \%$ and $2 \mathrm{~mL}$ of toluene were added to the mixture, followed by agitation in the vortex. After being centrifuged for 5 minutes at $340 \times \mathrm{g}$ (Compact II Centrifuge, Clay Adams, USA), the organic phase was separated and dried with $\mathrm{Na}_{2} \mathrm{SO}_{4}$ anhydride. The organic phase $(1 \mathrm{~mL})$ was filtered with a $0.45 \mu \mathrm{m}$ membrane. A $3 \mu \mathrm{L}$ sample of this solution was injected onto the GC system. The equipment consisted of a gas chromatograph with a flame ionization detector, with a CP-Sil 5 CB capillary column and a CP-8410 auto-injector, all Varian Inc. (Palo Alto, CA, USA) manufactured. The injection volume was $3 \mu \mathrm{L}$ (at $\left.250{ }^{\circ} \mathrm{C}\right)$, the carrier gas was helium $(1 \mathrm{~mL} /$ minute $)$ and the detector temperature was maintained at $270{ }^{\circ} \mathrm{C}$. The column temperature was held at $110^{\circ} \mathrm{C}$ for 1 minute and then increased to $240{ }^{\circ} \mathrm{C}$ at a rate of $3{ }^{\circ} \mathrm{C} /$ minute, which was maintained for 15 minutes. Peak identifications were based on the comparison of retention times to the standards--the area of the peaks was quantified by using the Galaxie Workstation (Varian Inc., Palo Alto, CA, USA) software. The relative amount of each fatty acid (\% of total fatty acids) was quantified by integrating the area 
under the peak and dividing the result by the total area for all fatty acids.

\section{Water and oil holding capacity}

The methodology described by Yeh, Su and Lee (2005) was implemented. To determine the water holding capacity, the samples $(1 \mathrm{~g})$ were suspended in $20 \mathrm{~mL}$ of distilled water. After 24 hours of repose at room temperature, the samples were centrifuged at 3,000 rpm for an hour. Supernatants were carefully discarded; then, the gel formed was weighed. The oil holding capacity was determined under similar conditions as those of water holding capacity using $6 \mathrm{~mL}$ of commercial corn oil (w/v) and a repose time of 6 hours. Water and oil holding capacity were reported as $g$ of water or oil/g of dry weight.

\section{Color}

A Minolta colorimeter determined the color of the flours from the cactus pear cladodes (Chroma Meter Model 410). The color parameters were matched to the scale: ${ }^{*} \mathrm{~L}$ (lightness), $\mathrm{a}^{*}$ (+ red; - green) and $\mathrm{b}^{\star}$ (+ yellow; - blue).

\section{Statistical analysis}

Data were statistically analyzed by applying one-way ANOVA and Tukey's test at a significance level of $0.05(\mathrm{p} \leq 0.05)$, using the SPSS for Windows version 11.0 (STATISTICAL PACKAGE FOR THE SOCIAL SCIENCES, 2001). The data were expressed as average $\pm \mathrm{SD}$ (standard deviation).

\section{Results and discussion}

\subsection{Cactus pear cladodes flours preparation}

The fresh Cactus pear cladodes had a high moisture content, $93.5 \mathrm{~g} .100 \mathrm{~g} \mathrm{~g}^{-1}$. The drying times at $60^{\circ} \mathrm{C}, 70^{\circ} \mathrm{C}$ and $80^{\circ} \mathrm{C}$ were 8 hours, 6 hours and 3 hours, respectively. These results confirmed that the drying at $80^{\circ} \mathrm{C}$ improved the mass transfer and velocity of drying; and also eliminated the period required for constant drying (KARATHANOS; VILLALOBOS; SARAVACOS, 1990; MALDONADO; PACHECO-DELAHAYE, 2003). Cactus pear cladodes showed long drying times in relation to the drying times of other vegetables, such as cauliflower and broccoli, what can be attributed to the impermeable cuticle on the surface of the cactus pear cladodes that function to prevent

Table 1. Proximate analysis of cactus pear cladodes flours g. $100 \mathrm{~g}^{-1}$ dry weight.

\begin{tabular}{lccc}
\hline \multirow{1}{*}{ Analysis } & \multicolumn{3}{c}{ Drying temperature } \\
\cline { 2 - 4 } & $60{ }^{\circ} \mathrm{C}$ & $70{ }^{\circ} \mathrm{C}$ & $80{ }^{\circ} \mathrm{C}$ \\
\hline Moisture content & $1.63 \pm 0.11$ & $1.93 \pm 0.07$ & $2.00 \pm 0.09$ \\
Crude protein & $7.52 \pm 0.05$ & $7.42 \pm 0.09$ & $7.24 \pm 0.13$ \\
Total lipid & $2.30 \pm 0.35$ & $2.30 \pm 0.37$ & $2.38 \pm 0.27$ \\
Crude fiber & $6.15 \pm 0.43$ & $6.04 \pm 0.23$ & $6.00 \pm 0.42$ \\
Ash & $20.46 \pm 0.30$ & $20.12 \pm 0.47$ & $20.78 \pm 0.12$ \\
Total carbohydrates & 68.09 & 68.23 & 67.6 \\
\hline
\end{tabular}

Data are expressed as means $\pm S D$ of 2 assays (by triplicate). Carbohydrates obtained by difference $(100-$ (moisture + protein + lipid + ash $)$. water evaporation. This study recovered $65 \mathrm{~g} . \mathrm{kg}^{-1}$ of fresh cactus pear cladodes.

\subsection{Proximate analysis}

The centesimal composition in the cactus pear cladodes flours is shown in Table 1 . There were no significant differences $(\mathrm{p} \leq 0.05)$ in protein, lipids and ash contents in the flours along the variation of the drying temperatures. During the preparation of dietary supplements, it is important to consider the maturity of the cactus pear cladodes. Young cactus pear cladodes are nutritionally superior to the more mature ones (MONDRAGÓN-JACOBO; PEREZ-GONZÁLEZ, 2001; RODRÍGUEZ-GARCÍA et al., 2007). For that reason, the cactus pear cladodes in the study were cut into $15 \pm 5 \mathrm{~cm}$ pieces, with a weight between $150 \mathrm{~g}$ to $200 \mathrm{~g}$. In general, the crude protein, total lipid, crude fiber and total ash contents of the flours, reported in this study, were similar to the information reported by Rosado and Díaz (1995); Sáenz (2000); Rodríguez-García et al. (2007) in cactus pear cladodes flours. On the other hand, the carbohydrates represented the main fraction of cactus pear cladodes flours, $68 \mathrm{~g} .100 \mathrm{~g}^{-1}$ dry weight. These results are similar to those reported by Malainine et al. (2003); Guzmán and Chávez (2007) in cactus pear cladodes. The variations presented in the previous studies can be a consequence of factors such as the variety, state of maturity and growing conditions of the vegetable (PAK, 1997, 2000; PRAKONGPAN; NITITHAMYONG; LUANGPITUKSA, 2002; GRANADOS, 2003). The chemical composition showed minimum differences when compared to the values reported for flours of other vegetable byproducts, such as carrot peels (CHANTARO; DEVAHASTIN; CHIEWCHAN, 2008).

\subsection{Total amino acids}

The content of total amino acids in cactus pear cladodes flours is presented in Table 2. Due to the nature of the vegetable, these flours have low protein and amino acids contents. In

Table 2. Amino acid content of the cactus pear cladodes flours (mg.g ${ }^{-1}$ dry weight).

\begin{tabular}{lccc}
\hline \multirow{2}{*}{ Amino acid } & \multicolumn{3}{c}{ Drying temperature } \\
\cline { 2 - 4 } & $60{ }^{\circ} \mathrm{C}$ & $70{ }^{\circ} \mathrm{C}$ & $80{ }^{\circ} \mathrm{C}$ \\
\hline Asp & $6.02 \pm 0.46$ & $5.38 \pm 0.34$ & $5.29 \pm 0.37$ \\
Glu & $6.35 \pm 0.39$ & $5.16 \pm 0.13$ & $5.74 \pm 0.24$ \\
Ser+His & $4.02 \pm 0.26$ & $2.60 \pm 0.84$ & $1.45 \pm 0.35$ \\
Gly & $3.28 \pm 0.18$ & $3.01 \pm 0.42$ & $2.57 \pm 0.17$ \\
Thr & $2.81 \pm 0.45$ & $2.56 \pm 0.35$ & $2.37 \pm 0.20$ \\
Ala & $0.54 \pm 0.13$ & $0.39 \pm 0.22$ & $0.37 \pm 0.70$ \\
Pro & $6.11 \pm 0.12$ & $5.97 \pm 0.12$ & $5.85 \pm 0.10$ \\
Tyr & $15.02 \pm 0.22$ & $13.84 \pm 0.29$ & $14.14 \pm 0.21$ \\
Arg & $2.63 \pm 1.07$ & $2.58 \pm 1.10$ & $2.77 \pm 1.30$ \\
Val & $3.73 \pm 0.80$ & $3.37 \pm 0.18$ & $3.60 \pm 0.30$ \\
Met & $\mathrm{ND}$ & $\mathrm{ND}$ & $\mathrm{ND}$ \\
Ile & $2.49 \pm 0.11$ & $2.22 \pm 0.19$ & $2.36 \pm 0.12$ \\
Leu & $2.27 \pm 0.14$ & $1.91 \pm 0.26$ & $2.20 \pm 0.50$ \\
Phe & $3.02 \pm 0.70$ & $2.72 \pm 0.15$ & $2.82 \pm 0.20$ \\
Total & 58.29 & 51.71 & 51.53 \\
\hline
\end{tabular}

Data are expressed as means \pm SD of 2 assays (by triplicate); $\mathrm{ND}=$ not detected. 
general, the amino acids found in greater concentration were the Tyr, Pro, Asp and Glu, which represented about $56 \%$ of the total content. In respect to the analyzed amino acids, the content of Ile, Phe, Tyr, Thr and Val are similar to those reported by Morales de León, Bourges and Camacho (2005) in fresh cactus pear cladodes; however, Leu was found in low concentrations and Met was not detected in the flours produced in this study. Thus, Met can be considered as a limited amino acid in the flours according to the reference standard by $\mathrm{FAO} / \mathrm{WHO}$ (FOOD AND AGRICULTURAL ORGANIZATION; WORLD HEALTH ORGANIZATION, 1991). The essential amino acids lysine and tryptophan were not quantified in this study. In respect to the amino acid profile, significant differences were found concerning the values reported by other authors (NEFZAOUI; SALEN, [19--]; STINTZING; CARLE, 2005), what is attributed to the cladodes variety and age, the weather, the type of soil and the growing conditions of the vegetable.

\subsection{Fatty acid composition}

The fatty acids compositions in the lipids from cactus pear cladodes flours are shown in Table 3 . The fatty acids identified were the following: acid (C14:1n5), myristic acid (C14:0), palmitoleic acid (C16:1n7), palmitic acid (C16:0), linoleic acid (C18:2n6), linolenic acid (C18:3n3), oleic acid (C18:1n9), vaccenic acid (C18:1n7), stearic acid (C18:0), arachidic acid (C20:0), gondoic acid (C20:1n9) and behenic acid (C22:0). In cactus pear cladodes flours, the most abundant fatty acids were palmitic acid (C16:0), linoleic acid (C18:2n6), linolenic acid (C18:3n3), and oleic acid (C18:1n9), which corresponded to $88 \%, 91 \%$ and $92 \%$ of the total fatty acids present in the cactus pear cladodes flours prepared in this study. Furthermore, the lipids present in the samples contained about $50 \%$ of the essential fatty acids (C18:2n6, C18:3n3), while the saturated fatty acid content was $37 \%$. The fatty acid profile observed in this study is similar to that reported for raw cactus pear cladodes (UNITED STATES DEPARTMENT OF AGRICULTURE, 2008). The lipids of the flours were rich in essential fatty acids,

Table 3. Fatty acid composition in the lipids of the cactus pear cladodes flours.

\begin{tabular}{|c|c|c|c|}
\hline \multirow[t]{2}{*}{ Fatty acid } & \multicolumn{3}{|c|}{ Fatty acid (area \%) } \\
\hline & $60^{\circ} \mathrm{C}$ & $70^{\circ} \mathrm{C}$ & $80^{\circ} \mathrm{C}$ \\
\hline C14:1n5 & $0.91 \pm 0.01$ & $1.07 \pm 0.04$ & $1.05 \pm 0.08$ \\
\hline C14:0 & $0.87 \pm 0.06$ & $0.62 \pm 0.03$ & $0.56 \pm 0.03$ \\
\hline C16:0 & $26.83 \pm 0.53$ & $30.21 \pm 0.38$ & $30.70 \pm 0.41$ \\
\hline C18:2n6 & $28.61 \pm 0.68$ & $26.92 \pm 0.68$ & $25.05 \pm 0.53$ \\
\hline C18:3n3 & $21.58 \pm 0.92$ & $22.99 \pm 0.82$ & $26.44 \pm 0.38$ \\
\hline C18:1n9 & $11.03 \pm 0.45$ & $10.66 \pm 0.18$ & $9.48 \pm 0.15$ \\
\hline $\mathrm{C} 18: \ln 7$ & $0.65 \pm 0.09$ & $0.53 \pm 0.04$ & $0.56 \pm 0.03$ \\
\hline C18:0 & $3.65 \pm 0.23$ & $3.79 \pm 0.19$ & $3.63 \pm 0.16$ \\
\hline C20:1n 9 & $0.41 \pm 0.05$ & $0.22 \pm 0.02$ & $0.18 \pm 0.02$ \\
\hline C20:0 & $1.11 \pm 0.03$ & $0.99 \pm 0.03$ & $0.99 \pm 0.02$ \\
\hline C22:0 & $4.00 \pm 0.56$ & $2.00 \pm 0.07$ & $1.36 \pm 0.07$ \\
\hline Saturated & 36.5 & 37.6 & 37.2 \\
\hline Monounsaturated & 13.0 & 12.5 & 11.3 \\
\hline Polyunsaturated & 50.2 & 49.9 & 51.5 \\
\hline
\end{tabular}

Data are expressed as means \pm SD of 2 assays (by triplicate). but the total lipid content was low (2.3\%) and; consequently, it does not represent a rich source of these nutrients.

\subsection{Water holding capacity}

The water holding capacity of cactus pear cladodes flours are shown in Figure 1. This property has been compared to the composition and structural changes of the dietary fiber in vegetables (FEMENIA et al., 1999). Positive health development has been attributed to dietary fiber present in cactus pear cladodes (SÁENZ; SEPÚLVEDA; MATSUHIRO, 2004). The flours prepared in this study showed a high water holding capacity, ranging from 6.48 to $14.44 \mathrm{~g}$ water/g dry sample. During the drying process at $70^{\circ} \mathrm{C}$ and $80^{\circ} \mathrm{C}$, the water holding capacity decreased to $43 \%$ and $55 \%$, respectively, with respect to the drying process at $60^{\circ} \mathrm{C}$. Moreover, in the flours produced at $80^{\circ} \mathrm{C}$, there was a decrease in the content of mucilage (information not shown). The results above are similar to those obtained by Lobato, Martínez and Chávez (2004). During the drying of cactus pear in a conventional oven, they reported water holding capacity of $10.03 \mathrm{~g}$ of water/g dry weight in the flours prepared at $50^{\circ} \mathrm{C}$ and of $4.4 \mathrm{~g}$ of water/g of dry weight in the flours obtained at $80^{\circ} \mathrm{C}$. In addition, in the cactus pear cladodes flours (young cladodes) grown by Rosado and Díaz (1995), the water holding capacity was $11.1 \mathrm{~g}$ water/g of dry weight. Also and Sáenz (1997) prepared cactus pear cladodes flours from old cladodes (1-3 years of age) yielding a water holding capacity of $5.6 \mathrm{~g}$ water/g dry weight, a value that is minimal compared to that obtained in this study. Some authors (WOLEVER et al., 1990; FEMENIA et al., 1997, 1999) reported that the drying conditions and the source of the fiber affect the functional properties of dehydrated powders. Due to its high water holding values, the cactus pear cladodes flour could be appropriate to improve texture in a variety of foods, such as bakery products or desserts.

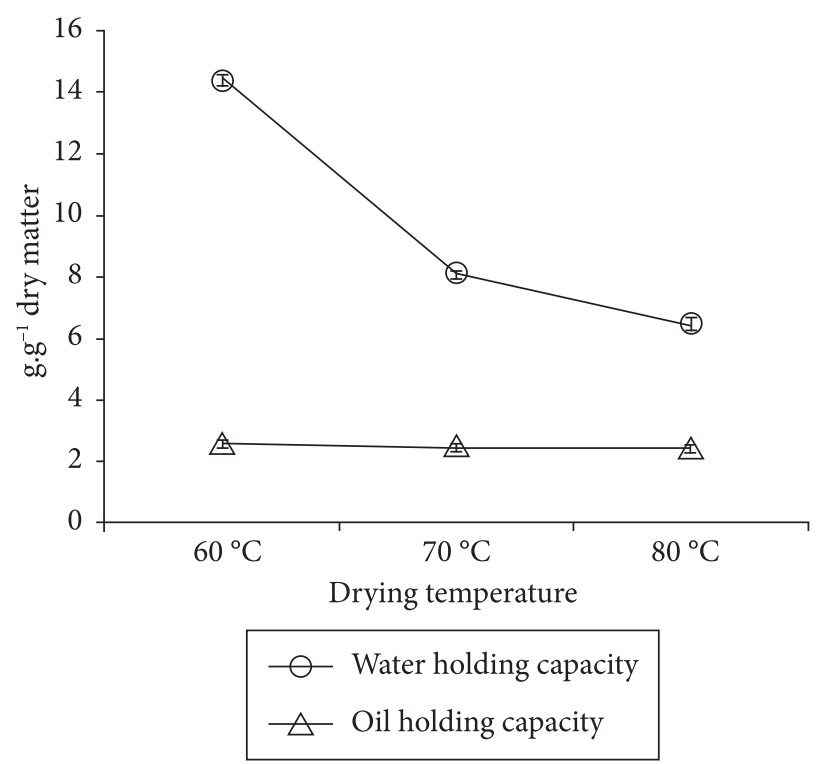

Figure 1. Water and Oil holding capacity from cactus pear cladodes flours during drying at $60^{\circ} \mathrm{C}, 70^{\circ} \mathrm{C}$ and $80^{\circ} \mathrm{C}$. 
Table 4. Color in cactus pear cladodes flours.

\begin{tabular}{lccc}
\hline \multirow{2}{*}{ Analysis } & \multicolumn{3}{c}{ Drying temperature } \\
\cline { 2 - 4 } & $60{ }^{\circ} \mathrm{C}$ & $70^{\circ} \mathrm{C}$ & $80{ }^{\circ} \mathrm{C}$ \\
\hline $\mathrm{L}^{*}$ (lightness) & $73.65 \pm 0.15^{\mathrm{a}}$ & $71.86 \pm 0.19^{\mathrm{b}}$ & $72.07 \pm 0.27^{\mathrm{b}}$ \\
$\mathrm{a}^{*}$ (green) & $-9.59 \pm 0.03^{\mathrm{a}}$ & $-6.31 \pm 0.02^{\mathrm{b}}$ & $-6.28 \pm 0.02^{\mathrm{b}}$ \\
$\mathrm{b}^{*}$ (yellow) & $24.67 \pm 0.21^{\mathrm{a}}$ & $23.13 \pm 0.05^{\mathrm{b}}$ & $26.75 \pm 0.14^{\mathrm{c}}$ \\
\hline
\end{tabular}

Data are expressed as means \pm SD of 2 assays (by triplicate). Means within a given row followed by different letters are significantly different at the $5 \%$ level.

\subsection{Oil holding capacity}

The oil holding capacity is an important parameter used to evaluate the hydrophobic nature of particles that constitute the fiber fraction, which is related to the emulsifying properties. There were no significant differences $(\mathrm{p} \leq 0.05)$ in the oil holding capacity of the cactus pear cladodes flours formed at $60{ }^{\circ} \mathrm{C}, 70^{\circ} \mathrm{C}$ and $80^{\circ} \mathrm{C}$ (Figure 1). These results differ from the reports from Femenia et al. (1997) in cauliflower flour and by Lobato, Martínez and Chávez (2004) in cactus pear cladodes flours. Those reports found a decrease in the oil holding capacity during the drying at high temperatures. In addition, Rosado and Díaz (1995) reported an oil holding capacity of $3.7 \mathrm{~g}$ of oil/g of dry weight in cactus pear cladodes flours. The differences in the values of the oil holding capacity of this work, in comparison to those reported by other authors, can be attributed to the variety and age of cladodes, the degree of milling of the flours and the drying conditions. The cactus pear cladodes flours prepared in this study had a lower oil holding capacity and, as consequence, unsuitable emulsifying properties.

\subsection{Color}

The color parameters of the cactus pear cladodes flours are shown in Table 4. In comparison to the flour obtained at $60^{\circ} \mathrm{C}$, the drying processes at $70^{\circ} \mathrm{C}$ and $80^{\circ} \mathrm{C}$ showed reduction of $3 \%$ and $34 \%$, respectively, in the color parameters $L^{\star}$ (luminosity) and $-\mathrm{a}^{\star}$ (green). In the case of parameter $\mathrm{b}^{\star}$ (yellow), there was an increase of $8 \%$ at $80^{\circ} \mathrm{C}$ temperature. The cactus pear cladodes flours obtained at $60^{\circ} \mathrm{C}$ conserved a major quantity of the green color, which is a desirable quality parameter for this product. Saénz (1997) reported cactus pear cladodes flours with similar color parameters in respect to luminosity $\left(\mathrm{L}^{*}: 73.37\right)$ and the yellow color $\left(b^{*}: 26.1\right)$, but with minor intensity of the green color $\left(\mathrm{a}^{*}:-5.20\right)$. The differences, in respect to this study, can be attributed to the drying temperature and the maturity of the cladodes, which resuled in the degradation of the chlorophyll to pheophytin (GUAN; CENKOWSKI; HYDAMAKA, 2005).

\section{Conclusions}

The application of high thermal treatments during the preparation of cactus pear cladodes flours affect the water absorption capacity (functional property) and the green color negatively. Presenting higher functional qualities, the cladodes flours processed at $60^{\circ} \mathrm{C}$ are considered the most adequate for the formulation of dietary supplements.

\section{Acknowledgements}

This research was financed under project no. 66073 with Mixed Funds of the government of the State of Sonora and the National Council for Science and Technology (FOMIX-CONACYT).

\section{References}

ASSOCIATION OF OFFICIAL ANALYTICAL CHEMISTS - AOAC. Official methods of Analysis of the Association of Official Analytical Chemists.14th ed. Arlington: AOAC, 1984.

BETANCOURT-DOMíngueZ, M. A. et al. Physico-chemical changes in cladodes (nopalitos) from cultivated and wild cacti (Opuntia spp.). Plant Foods for Human Nutrition, v. 61, p. 115-119, 2006. PMid:17031603. http://dx.doi.org/10.1007/s11130-0060008-6

CHANTARO, P.; DEVAHASTIN, S.; CHIEWCHAN, N. Production of antioxidant high dietary fiber powder from carrot peels. LWT- Food Science and Technology, v. 41, n. 10, p. 1987-1994, 2008.

DE LA ROSA, H. J. SANTANA, A. D. El nopal: usos, manejo agronómico y costos de producción en México. México: Editorial Conaza-Uach-Ciestaam, 1998. p. 30-31.

DUKAS, L.; WILLETT, C. W.; GIOVANNUCCI, L. E. Association between physical activity, fiber intake and other lifestyle variables and constipation in a study of women. American Journal of Gastroenterology, v. 98, p. 1790-1796, 2003. PMid:12907334. http:// dx.doi.org/10.1111/j.1572-0241.2003.07591.x

FEMENIA, A. et al. Physical and sensory properties of model foods supplemented with cauliflower fiber. Journal of Food Science, v. 62, p. 635-639, 1997. http://dx.doi.org/10.1111/j.1365-2621.1997. tb15426.x

FEMENIA, A. et al. Effects of heat treatment and dehydration on properties of cauliflower fiber. Journal of Agriculture and Food Chemistry, v. 47, p. 728-732, 1999. PMid:10563960. http://dx.doi. org/10.1021/jf980462k

FEUGANG, M. J. et al. Nutritional and medicinal use of Cactus pear (Opuntia spp) cladodes and fruits. Frontiers in Bioscience, v. 11, p. 2574-2589, 2006. PMid:16720335. http://dx.doi.org/10.2741/1992

FOOD AND AGRICULTURAL ORGANIZATION - FAO; WORLD HEALTH ORGANIZATION - WHO. Protein quality evaluation. Rome: FAO/WHO, 1991. Disponível em: <http://faostat.fao.org/ site/567/default.aspx\#ancor>. Acesso em: 11 jun. 2007.

GRANADOS, S. D. El nopal: historia, fisiología, genética e importancia frutícola. México: Editorial Trillas, 2003. p. 5-10.

GUAN, T. T. Y.; CENKOWSKI, S.; HYDAMAKA, A. Effect of drying on the nutraceutical quality of Sea Buckthorn (Hippophae rhamnoides L.ssp.sinensis) leaves. Journal of Food Science, v. 70, p. 514-518, 2005. http://dx.doi. org/10.1111/j.1365-2621.2005.tb08312.x

GÚZMAN, L. D.; CHAVÉZ, J. Estudio bromatológico del cladodio del nopal (Opuntia ficus-indica) para el consumo humano. Revista de la Sociedad Química de Perú, v. 73, p. 41-45, 2007.

KARATHANOS, V.; VILLALOBOS, G.; SARAVACOS, G. Comparison of two methods of estimation of the effective moisture diffusivity from drying data. Journal of Food Science, v. 55, p. 218-223, 1990. http://dx.doi.org/10.1111/j.1365-2621.1990.tb06056.x

KWOK, B. H. L. et al. Dehydration techniques affect phytochemical contents and free radical scavenging activities of Saskatoon berries (Amelanchier alnifolia Nutt.). Journal of Food Science, v. 69, p. 122-126, 2004.

LEE, S.; CHUNG, S.; LEE, I. The antidiabetic effect of dietary Persimmon (Diospyros kaki L. cv. Sangjudungsi) peel in streptozotocin-induced 
diabetic rats. Journal of Food Science, v. 71, p. 293-298. 2006. http://dx.doi.org/10.1111/j.1365-2621.2006.tb15656.x

LOBATO, S. V.; MARTÍNEZ, F. H. E.; CHÁVEZ, L. G. Estudio de algunas propiedades fisicoquímicas del nopal (Opuntia sp.) deshidratado a diferentes temperaturas. Revista Chilena de Nutrición, v. 31, 2004. Suplemento 1.

LÓPEZ-CERVANTES, J.; SÁNCHEZ-MACHADO, D. I.; ROSAS-RODRÍGUEZ, J. A. Analysis of free amino acids in fermented shrimp waste by high-performance liquid chromatography. Journal of Chromatography A, v. 1105, p. 106-110, 2006. PMid:16439254. http://dx.doi.org/10.1016/j.chroma.2005.08.040

MALAININE, M. E. et al. Structure and morphology of cladodes and spines of Opuntia ficus-indica. Cellulose extraction and characterization. Carbohydrate Polymers, v. 51, p. 77-83, 2003. http://dx.doi.org/10.1016/S0144-8617(02)00157-1

MALDONADO, R. J.; PACHECO-DELAHAYE, E. Curvas de deshidratación del brócoli (Brassica olereaceae L var. Italica Plenk) y coliflor (Brassica olereaceae L var. Botrytis L). Revista de la Facultad de Agronomía, v. 20, p. 306-319, 2003.

MONDRAGÓN-JACOBO, C.; PEREZ-GONZÁlEZ, S. Cactus (Opuntia spp.) as Forage. Rome: FAO, CIT: 2000. (FAO plant production and protection paper, n. 169).

MORALES DE LEÓN, J.; BOURGES, H.; CAMACHO, M. E. Amino acid composition of some mexican foods. Archivos Latinoamericanos de Nutrición, v. 55, p. 172-186, 2005. PMid:16335228.

NEFZAOUI, A.; SALEN, H. B. Opuntiae: A strategic fodder and efficient tool to combat desertification in the Wane region. International Committee of Cactusnet-FAO, [19--]. http://www. fao.org/ag/AGP/AGPC/doc/PUBLICAT/Cactusnt/cactus2.htm

O CONNOR, C. J. et al. Effect of soluble dietary fibers on lipase-catalyzed hydrolysis of tributyrin. Journal of Food Science, v. 68, p. 1093-1099, 2003. http://dx.doi.org/10.1111/j.1365-2621.2003.tb08294.x

OU, S. et al. In vitro study of posible role of dietary fiber in lowering postprandial serum glucose. Journal of Agriculture and Food Chemistry, v. 49, p. 1026-1029, 2001. PMid:11262066. http://dx.doi. org/10.1021/jf000574n

PAK, D. N. Análisis de fibra dietética. In: MORÓN, C.; ZACARÍAS, I.; DE PABLO, S. (Eds.). Producción y manejo de datos de composición química de alimentos en nutrición. Santiago de Chile: FAO-INTA, 1997. p. 177-187.

PAK, D. N. Fibra dietética en verduras cultivadas en chile. Archivos Latinoamericanos de Nutrición, v. 50, p. 97-101, 2000.

PRAKONGPAN, T.; NITITHAMYONG, A.; LUANGPITUKSA, P. Extraction and application of dietary fiber and cellulose from pineapple cores. Journal of Food Science, v. 67, p. 1308-1313, 2002. http://dx.doi.org/10.1111/j.1365-2621.2002.tb10279.x

RODRÍGUEZ-FÉLIX, A.; VILLEGAS-OCHOA, M. A. Quality of cactus stems (Opuntia ficus-indica) during low-temperature storage. Journal of the Professional Association for Cactus Development, v. 2, p. 142-152, 1997.
RODRÍGUEZ-GARCIA, M. E. et al. Physicochemical characterization of nopal pads (Opuntia ficus indica) and dry vacuum nopal powders as a function of the maturation. Plant Foods for Human Nutrition, v. 62 , p. 107-112, 2007. http://dx.doi.org/10.1007/s11130-0070049-5

ROSADO, J. L.; DÍAZ, M. Propiedades fisicoquímicas relacionadas con función gastrointestinal de seis fuentes de fibra dietética. Revista de Investigación Clínica, v. 47, p. 283-289, 1995.

SÁENZ, C. Processing technologies: an alternative for cactus pear (Opuntia spp.) fruits and cladodes. Journal of Arid Enviroment, v. 46, p. 209-225, 2000. http://dx.doi.org/10.1006/jare.2000.0676

SÁENZ, C. et al. Uso de fibra dietética de nopal en la formulación de un polvo para flan. Archivos Latinoamericanos de Nutrición, v. 52, p. 387-392, 2002.

SÁENZ, C. et al. Utilización agroindustrial del nopal. 1ra. Edición. Boletín de Servicios Agrícolas de la FAO 162, Roma, 2006. 170 p.

SAÉNZ, C.; SEPÚlVEDA, E.; MATSUHIRO, B. Opuntia spp mucilage's : a functional component with industrial perspectives. Journal of Arid Environments, v. 57, p. 275-290, 2004. http:// dx.doi.org/10.1016/S0140-1963(03)00106-X

SÁENZ, C. H. Cladodes: a source of dietary fiber. Journal of the Professional Association for Cactus Development, v. 2, p. 117-123, 1997.

SÁNCHEZ-MACHADO, D. I. et al. Fatty acids, total lipid, protein and ash contents of processed edible seaweeds. Food Chemistry, v. 85, p. 439-444, 2004. http://dx.doi.org/10.1016/j.foodchem.2003.08.001

SISTEMA INTEGRAL DE INFORMACIÓN AGROALIMENTARIA Y PESQUERA - SIAP/SAGARPA. Anuario Estadístico de la Producción Agrícola. 2008.

STATISTICAL PACKAGE FOR THE SOCIAL SCIENCES - SPSS. SPSS 11.0 for Windows. Chicago: SPSS Inc., 2001.

STINTZING, F. C.; CARLE, R. Cactus stems (Opuntia spp.): A review on their chemistry, technology, and uses. Molecular Nutrition \& Food Research, v. 49, p. 175-194, 2005. http://dx.doi.org/10.1002/ mnfr.200400071

TORRECILLA, J. S.; ARAGÓN, M. J.; PALANCAR, C. M. Modeling the drying of a high-moisture solid with an artificial neural network. Industrial \& Engineering Chemistry Research, v. 44, p. 8057-8066, 2005. http://dx.doi.org/10.1021/ie0490435

UNITED STATES DEPARTMENT OF AGRICULTURE - USDA. National Nutrient Database for Standard Reference. Agricultural research Service, 2008. Disponível em: <http://www.nal.usda.gov/ fnic/foodcomp/search/>. Acesso em: 10 ago. 2007.

WOLEVER, T. M. S. Relationship between dietary fiber content and composition in foods and the glycemic index. American Journal of Clinical Nutrition, v. 51, p. 72-75, 1990.

YEH, H. Y.; SU, N. W.; LEE, M. H. Chemical Compositions and Physicochemical Properties of the Fiber-Rich Materials Prepared from Shoyu Mash Residue. Journal of Agriculture and Food Chemistry, v. 53, p. 4361-4366, 2005. PMid:15913296. http://dx.doi. org/10.1021/jf050243g 